\title{
A COMPANY'S MARKETING MIX IN TERMS OF GLOCAL MARKETING
}

\author{
Kateryna BEKH ${ }^{1}$ \\ Institute of International Relations of Taras Shevchenko National University of Kyiv, Ukraine
}

\begin{abstract}
The purpose of the paper is to sum up the theoretical foundations of glocal marketing and the peculiarities of display of such marketing on the example of marketing mix of Mondelezz International. Methodology. A large amount of available sources of information devoted to glocal marketing is analysed in order to achieve the purpose of the research. The research covers and highlights the concepts and ideas concerning this marketing, the sources of which are works that meet such requirements of information as relevance and reliability best of all. MOreover, the author's definition of the concept of glocal marketing is given. Mondelēz International is considered in the paper as an example of a company that uses the glocal approach in marketing. The choice of a company for analysis is so, in particular, because various representatives of Mondelèz International argue that this company uses a glocal strategy to promote its products in different countries of the world. Marketing mix of Mondelez International is considered in the paper on the example of products under such trademarks as Barni, belVita, Oreo, Picnic, Tang and Toblerone. Results. The paper sums up the theoretical foundations of glocal marketing and considers the practical examples of the use of such marketing. There are numerous differences between countries, such as: social, technological, economic, environmental, political, legal and ethical. It means that marketing has common and distinctive features in different countries. The local aspects of marketing activities have an impact on the determination of global marketing orientation of a company. At the same time, every global marketing problem has its local display, and therefore requires a glocal approach in solving the problem. Glocal marketing is marketing combining the advantages of global and local approaches, taking into account trends and changes in the marketing environment generated by the dialectics of unity and struggle of the global and the local. Combining the ideas of global marketing and local marketing allows allay or even completely avoid the shortcomings occurring if only global or only local approach is used. The same products of a company may be under another trademarks, have a variety of flavours or forms depending on a country. The product price correlates with inputs. Mondelezz International often chooses the reduction of its product weight rather than the rise of product price. Mondelēz International sells its products in 165 countries organized into five segments. Each segment has its own structure of product consumption and other peculiarities. The product promotion depends on the features of a product. The positioning of a product may not differ in different countries, but advertising may be altered depending on the market if needed. The analysis of different sources of information as well as the research of marketing mix confirms with specific examples that Mondelezz International uses glocal marketing. Practical implications. The advantages and at the same time the distinctive features of the implementation of glocal marketing are marked out while considering the theoretical foundations of the research. Such distinctive features have also been supported by specific examples of activities of Mondelēz International. The research has confirmed the existing theoretical achievements in the field of glocal marketing. The research is also a continuation and further development of these achievements, concepts and ideas. Value/originality. Specific examples of activities of Mondelèz International, adduced in the paper, combined with theoretical foundations of the issue of glocal marketing, are logically united and mutually complementary. The further development of scientific understanding of the concept of glocal marketing is obtained, as well as the implementation of its principles in practice. It will help, in particular, to large transnational corporations to conduct efficiently their activities in markets of different countries under conditions of cultural differentiation manifested in diversity of needs, tastes and preferences of local consumers. All this is intended for the reduction of costs and the increase of revenues of such corporations in conditions of the current marketing environment, as well as the maximization of satisfaction of the customers' needs in different countries.
\end{abstract}

Key words: glocal marketing, glocalization, Mondelēz International, marketing mix, global approach, local approach, needs of local consumers.

JEL Classification: D12, F23, F61, M31

Corresponding author:

${ }^{1}$ Department of International Business, Institute of International Relations of Taras Shevchenko National University of Kyiv.

E-mail: katerynabekh@gmail.com 


\section{Introduction}

Researches of various authors confirm the existence of numerous differences between countries in different dimensions of STEEPLE analysis: social, technological, economic, environmental, political, legal and ethical. Economic features of the latter dimension are studied mostly in terms of cross-cultural management. However, ethical (cultural) and other components of STEEPLE analysis are also highly important for marketing of companies that operate in conditions of heterogeneity of marketing environment in different countries. First of all, it regards the peculiarities of needs, tastes and preferences of local consumers.

Marketing has common and distinctive features in different countries. Common features are observed not only among countries sharing the common history. After all, the traditional marketing mix (product, price, place and promotion) dictates the marketing foundations applicable to practically any market conditions of some country. At the same time, every country has its own STEEPLE and other peculiarities of development. It means that product, price, place and promotion may differ depending on the country where products are sold. Thus, the local aspects of marketing activities have an impact on the determination of global marketing orientation of a company. At the same time, every global marketing problem has its local display, and therefore requires a glocal approach in solving the problem.

\section{Theoretical foundations of glocal marketing}

According to Dacko, glocal marketing is "marketing on a global scale that emphasizes customization at the level of local culture. Glocal marketing involves a combination of global marketing and local marketing" (Dacko, 2008). The Ukrainian researcher Zhukov considers that "companies should think globally while realizing strategic marketing, and act locally while realizing operational (tactical) marketing with a focus on some regional features" (Zhukov, 2015). He uses the concept of "glocalization" as "a positive phenomenon of development of international business in general and international marketing activities in particular", as "an effective and promising hybrid of two current trends - globalization and localization (regionalization)" (Zhukov, 2015). There are also other researchers using the concept of glocalization in marketing. In particular, the American researcher Kotler defines glocalization as "the strategy of introducing well-known international brands into another country with appropriate local adaptations" (Mirae Asset Global Investments, 2014).

The author defines the glocal marketing as marketing combining the advantages of global and local approaches, taking into account trends and changes in the marketing environment generated by the dialectics of unity and struggle of the global and the local. The advantages and at the same time the distinctive features of the implementation of glocal marketing are:

- marketing strategy's conformity with the processes of globalization and localization;

- economies of scale thanks to partial standardization and mass marketing, combined with due attention to peculiarities of traditions, demand, needs, tastes and preferences of local consumers;

- taking into account STEEPLE and other features of development at the global and local levels;

- sufficiently rapid reaction to global and local changes in the marketing environment of business activities;

- use of experience and achievements obtained in some countries to improve a company's marketing activities in other countries.

Resulting from the aforementioned, the glocal marketing combines the advantages of global marketing and local marketing. Such synthesis allows allay or even completely avoid the shortcomings occurring if only global or only local approach is used.

\section{Glocal marketing of Mondelēz International}

Mondelēz International, Inc. is one of the world's largest snack companies with lobal net revenues of $\$ 29.6$ billion and earnings from continuing operations of $\$ 7.3$ billion in 2015 (Mondelēz International, 2016a). In Ukraine, the products of the company are sold under such trademarks as Barni, belVita, Dirol, Halls, Korona, Luxe, Milka, Oreo, Picnic, Toblerone, TUC and others.

Various representatives of the company argue that Mondelez International uses a glocal strategy to promote its products in different countries of the world. Mary Beth West, Head of Marketing of Mondelezz International (York, 2012), and Chris Montenegro McGrath, Vice President of Global Public Affairs and Sustainability and WellBeing of Mondelèz International (Ramakrishnan, 2015), are among such representatives. Even Irene Rosenfeld, Chairman and Chief Executive Officer of Mondelēz International, emphasizes that the company uses a glocal strategy meaning the pairing of global ideas and local insights (Goudreau, 2013), (Yale School of Management, 2014). Information about the glocal approach in marketing of Mondelēz International can be found on the company's official website (Mondelēz International, 2016, p. 3), (Kraft Foods, 2010), (Kraft Foods, 2012), in researches and articles (Silverstein, Singhi, Liao \& Michael, 2012, pp. 141-142), (Ferrante, 2015, p. 4), (Khosla \& Sawhney, 2013), (Pringle, 2013), (Singapore Management University, 2013), (The Philippine Beat, 2015), (Clearing Customs, 2012), (Alexander, 2013).

The research of 4P's of marketing of Mondelēz International below confirms the company's use of glocal marketing.

Product. Mondelēz International sells Barni products in more than 40 countries. But these products may be 
under other trademarks in some countries, for instance, Barny in the UK, Ourson in France, Brumik in Czechia, and Teddy Grahams in North America (Mondelēz International, 2016b, p. 1).

The Picnic snacks have been being sold in Ukraine since 1993. This snack can also be bought in other countries but it may be called otherwise, for example, Mr.Big in Canada and Lunch Bar in Australia (Mondelezz International, 2016).

Tang is a billion-dollar brand of Mondelēz International. This beverage is sold in approximately 35 countries and is available in a variety of flavours based on local consumers' preferences. Orange flavour tops the Tang sales worldwide but local flavours make up 25 per cent of Tang sales in emerging markets. Different flavours gained popularity among consumers in different countries, for instance, orange, orange-mango, apple in Argentina; orange, grape, pineapple in Brazil; orange, orangepeach, lemon in China; tamarind, horchata in Mexico; orange, mango in the Middle East; honey lemon, mango in the Philippines (Mondelèz International, 2016f).

When Mondelez International launched Oreo in China, its cookies were too sweet, too big and too expensive for Chinese consumers. So Oreo was adapted to the Chinese market tailoring to local tastes and basing on a global platform. Today Oreo is sold with locally relevant flavours like Oreo Green Tea Ice Cream and in more affordable forms like wafers in China. It is an example of keeping the global brand architecture intact but adapting it to local consumer needs. Owing to the aforementioned, Oreo has become the number one among cookies in China and this country is now Oreo's second largest market in the world. Moreover, Oreo Thins, created in China, have been successfully launched in the USA and Australia (Mondelēz International, 2016e).

Price. Like many other companies, Mondelēz International is experiencing higher costs for numerous ingredients. The company tries to carry such costs for as long as possible but when further restraint of its product price rise is impossible, the company has to reduce the weight of its products to keep the prices at a level acceptable to consumers. In 2016 many food manufacturers raised their product prices due to the falling value of the pound following the Great Britain's decision to leave the European Union. So Mondelezz International had to reduce the weight of the Toblerone $400 \mathrm{~g}$ bars to $360 \mathrm{~g}$ and the $170 \mathrm{~g}$ bars to $150 \mathrm{~g}$ in the UK without changes in packaging or price but changing the form of bars to ensure Toblerone remained on-shelf and was affordable to consumers (BBC news, 2016). In such a way the company tries to avoid significant price increases for their products choosing the reduction of its product weight rather than the rise of product price.

Place. Mondelèz International sells its products in 165 countries (Mondelēz International, 2016a, p. 1). The company's operations and management structure are organized into five reportable operating segments (Mondelēz International, 2016a):

1) Latin America;

2) Asia Pacific;

3) Eastern Europe, Middle East and Africa ("EEMEA");

4) Europe;

5) North America.

There are different structures of product consumption in different segments (Table 1). Europe is a segment, which brought the largest percentage of the company's net revenues in $2015-35.5 \%$, where chocolate gained the largest percentage $-15.6 \%$ of the company's net revenues in 2015; biscuits (including cookies, crackers and salted snacks) $-8.2 \%$; beverages $-5.2 \%$; cheese and grocery $-3.9 \%$; gum and candy $-2.6 \%$. At the same time Mondelez International gained the largest percentage of the 2015 net revenues from the sales of products under the Biscuit category - 38.5\%. Almost the half of the abovementioned number is from the North America segment, where biscuits have the largest percentage $18.8 \%$ of the company's net revenues in 2015; gum and candy $-3.9 \%$; chocolate $-0.8 \%$. In Latin America the Biscuits category also has the largest percentage while in Europe, Asia Pacific and EEMEA the largest numbers has the Chocolate category.

Promotion. Mondelèz International positions belVita in various countries as breakfast biscuit. The choice of such kind of positioning is entailed by the fact that the consumers' breakfast issue may be considered in both local and global aspects. Breakfast in a local understanding has some peculiarities depending on a country. Meanwhile there are also global problems

Table 1

Percentage of 2015 Net Revenues of Mondelēz International by Product Category

\begin{tabular}{|c|c|c|c|c|c|c|}
\hline \multirow{2}{*}{ Segment } & \multicolumn{5}{|c|}{ Product Category } & \multirow{2}{*}{ Total } \\
\hline & Biscuits & Chocolate & Gum \& Candy & Beverages & Cheese \& Grocery & \\
\hline Latin America & $5.4 \%$ & $2.8 \%$ & $3.7 \%$ & $2.6 \%$ & $2.3 \%$ & $16.8 \%$ \\
\hline Asia Pacific & $4.3 \%$ & $4.9 \%$ & $2.4 \%$ & $1.4 \%$ & $1.8 \%$ & $14.8 \%$ \\
\hline EEMEA & $1.8 \%$ & $3.1 \%$ & $1.8 \%$ & $1.8 \%$ & $0.9 \%$ & $9.4 \%$ \\
\hline Europe & $8.2 \%$ & $15.6 \%$ & $2.6 \%$ & $5.2 \%$ & $3.9 \%$ & $35.5 \%$ \\
\hline North America & $18.8 \%$ & $0.8 \%$ & $3.9 \%$ & - & - & $23.5 \%$ \\
\hline Total & $38.5 \%$ & $27.2 \%$ & $14.4 \%$ & $11.0 \%$ & $8.9 \%$ & $100.0 \%$ \\
\hline
\end{tabular}

(Mondelēz International, 2016a, p. 4) 
related to the issue, for instance, many people around the world do not pay the required attention to breakfast, often skipping it due to feeling too pressed for time. belVita rapidly gained sales popularity even in markets where breakfast biscuits were an entirely new concept. belVita is transforming the breakfast category by creating a new mainstream biscuit occasion. Today this biscuit is sold in more than 50 countries in such positioning (Mondelēz International, 2016c, p. 1). And in 2015 belVita was introduced in China as the first breakfast biscuit (Mondelēz International, 2016c).

However, the positioning of a product may not always be appropriate for all countries where the company is represented. For instance, Oreo is famous in various countries with its Twist, lick, dunk ritual. But in different countries the Oreo advertising campaign characters can be different, for example, a boy and his father, a mother and her son, a boy and his dog, and other combinations. The advertising campaign prepared by Mondelez $z$ International is tested with local consumers to see what resonates best before starting the campaign in some country. And local employees of the company determine which variant suits best for a particular country.

Thus, the marketing mix of the company's products corresponds to glocal ideas, confirming the use of glocal marketing by Mondelēz International.

\section{Conclusions}

The purpose of the research has been achieved in the paper, i.e. summing-up of the theoretical foundations of glocal marketing and the peculiarities of display of such marketing on the example of marketing mix of Mondelez International has been made. And the following conclusions have been drawn:

1. There are numerous differences between countries, such as: social, technological, economic, environmental, political, legal and ethical. It means that marketing has common and distinctive features in different countries. The local aspects of marketing activities have an impact on the determination of global marketing orientation of a company. At the same time, every global marketing problem has its local display, and therefore requires a glocal approach in solving the problem.

2. Glocal marketing is marketing combining the advantages of global and local approaches, taking into account trends and changes in the marketing environment generated by the dialectics of unity and struggle of the global and the local. Combining the ideas of global marketing and local marketing allows allay or even completely avoid the shortcomings occurring if only global or only local approach is used.

3. The same products of a company may be under another trademarks, have a variety of flavours or forms depending on a country.

4. The product price correlates with inputs. Mondelèz International often chooses the reduction of its product weight rather than the rise of product price.

5. Mondelèz International sells its products in 165 countries organized into five segments. Each segment has its own structure of product consumption and other peculiarities.

6. The product promotion depends on the features of a product. The positioning of a product may not differ in different countries, but advertising may be altered depending on the market if needed.

7. The analysis of different sources of information as well as the research of marketing mix confirms with specific examples that Mondelēz International uses glocal marketing.

8. The prospects for further researches in the field of glocal marketing cover theoretical and practical aspects of the issue, because glocal marketing is used not only by companies that say openly about their use of glocal approach. This type of marketing is also typical of companies using the global basis for their activities and applying the necessary adaptations in marketing according to peculiarities of a country. The further research of glocal marketing is called upon to find the most optimal ratio of the global and the local in glocal marketing approach. In its turn, it will allow to determine the most optimal strategy of the reduction of costs and the increase of revenues, while meeting the needs of local consumers in different countries.

\section{References}

Alexander, D. (2013, June 06). Big in China: Jumbo shrimp pizza and green tea Oreos. Empower Network. Retrieved from: http://donaldalexander.empowernetwork.com/blog/big-in-china-jumbo-shrimp-pizza-andgreen-tea-Oreos

BBC news. (2016, 8 November). Toblerone triangle change upsets fans. BBC news. Retrieved from: http://www.bbc.com/news/uk-37904703

Clearing Customs. (2012, May 26). Grilled-Corn KitKats and Other Worldly Cuisine. Clearing Customs. Retrieved from: http://clearingcustoms.net/tag/glocalization

Dacko, S.G. (2008). The Advanced Dictionary of Marketing: Putting Theory to Use. NY: Oxford University Press, $601 \mathrm{p}$.

Ferrante, J. (2015). Sociology: A Global Perspective (9th ed.). Stamford: Cengage Learning, 413 p.

Goudreau, J. (2013, Mar 27). The Cookie Crumbles: Can Mondelez Find Its Mojo? Forbes. Retrieved from: http://www.forbes.com/sites/jennagoudreau/2013/03/27/the-cookie-crumbles-can-mondelez-find-itsmojo/\#745a23d533c0 
Khosla, S., \& Sawhney, M. (2013). Blank Checks: Unleashing the Potential of People and Businesses. M-Prize. Retrieved from: http://www.mixprize.org/hack/blank-checks-unleashing-potential-people-andbusinesses? challenge $=161$

Kraft Foods. (2010). 2010 Annual Report of Kraft Foods Inc. Form 8-K. Retrieved from: http://ir.mondelezinternational.com/secfiling.cfm?filingid=1193125-10-210222\&cik=1103982

Kraft Foods. (2012). 2012 Annual Report of Kraft Foods Inc. Form 8-K. Retrieved from: http://ir.mondelezinternational.com/secfiling.cfm?filingid=1193125-12-382930\&cik=1103982

Mirae Asset Global Investments. (2014, Q1). Globalization and Glocalization: special interview with Philip Kotler. Emerging Markets Insight. Mirae Asset Global Investments, 4-7.

Mondelēz International. (2016a). 2015 Annual Report of Mondelēz International. Form 10-K. Retrieved from: http://ir.mondelezinternational.com/secfiling.cfm?filingID=1193125-16-469394\&CIK=1103982

Mondelēz International. (2016b). Barni. 2016 Fact Sheet. Retrieved from: http://www.mondelezinternational. $\mathrm{com} /$ /media/MondelezCorporate/Uploads/downloads/Barni_fact_sheet.pdf

Mondelēz International. (2016c). BelVita. 2016 Fact Sheet. Retrieved from http://www.mondelezinternational. $\mathrm{com} / \sim /$ media/MondelezCorporate/Uploads/downloads/belVita_Fact_Sheet.pdf

Mondelēz International. (2016d). Nashi brendy. Retrieved from: http://ua.mondelezinternational.com/brandfamily

Mondelēz International. (2016e). Research, Development \& Quality. 2016 Fact Sheet. Retrieved from: http://www.mondelezinternational.com/ /media/MondelezCorporate/Uploads/downloads/RDQ Fact_Sheet.pdf

Mondelēz International. (2016f). Tang. 2016 Fact Sheet. Retrieved from: http://www.mondelezinternational.com/ $\sim /$ media/MondelezCorporate/Uploads/downloads/Tang_Fact_Sheet.pdf

Pringle, A. (2013, April 24). The woman behind Mondelez. Medill Reports. Retrieved from: http://newsarchive.medill.northwestern.edu/chicago/news-220468.html

Ramakrishnan, U. (2015). Marketing for a Greener World. Hispanic Executive. Retrieved from: http://hispanicexecutive.com/2015/mondelez

Silverstein, M.J., Singhi, A., Liao, C., \& Michael, D. (2012). The \$10 Trillion Prize: Captivating the Newly Affluent in China and India. Boston: Harvard Business Review Press, 314 p.

Singapore Management University. (2013, 26 Jun). Glocal warming. Singapore Management University. Retrieved from: http://www.smu.edu.sg/perspectives/2013/06/26/glocal-warming

The Philippine Beat. (2015, May 14). Mondelez Philippines 'glocalizes' products to bring delicious moments of joy. The Philippine Beat. Retrieved from: http://philippinebeat.com/2015/05/mondelez-philippines-glocalizesproducts-to-bring-delicious-moments-of-joy

Yale School of Management. (2014, May 1). Mondelēz International CEO Irene Rosenfeld on Strategy in the Global Snack Market. Yale School of Management. Retrieved from: http://som.yale.edu/news/2014/05/ mondel\%C4\%93z-international-ceo-irene-rosenfeld-strategy-global-snack-market

York, E.B. (2012, March 29). Kraft marketing chieflooks to Mondelez, trying new marketing tools. Chicago Tribune. Retrieved from: http://articles.chicagotribune.com/2012-03-29/business/ct-biz-0322-kraft-q-a-20120320_1_ kraft-foods-global-snacking-kraft-marketing

Zhukov, S.A. (2015). Mizhnarodna marketynhova diialnist pidpryiemstv v umovakh hlokalizatsii. Zbirnyk naukovykh prats Khmelnytskoho kooperatyvnoho torhovelno-ekonomichnoho instytutu. Economic sciences, 9, 415-418.

\section{Катерина БЕX}

\section{МАРКЕТИНГ-МИКС КОМПАНИИ ПРИ ГЛОКАЛЬНОМ МАРКЕТИНГЕ}

Аннотация. Целью работы является обобщение теоретических основ глокального маркетинга и особенностей проявления данного маркетинга на примере маркетинг-микса компании «Mondelēz International». Методика. Для достижения цели исследования был проанализирован большой объем доступных источников информации о глокальном маркетинге. Для данного исследования были выбраны и освещены те концепции и идеи о данном маркетинге, источниками которых являются работы, которые наилучшим образом соответствуют требованиям актуальности и достоверности информации. Также дано авторское определение понятия «глокальный маркетинг». «Mondelēz International» была рассмотрена в данной работе в качестве примера компании, которая использует глокальный подход в маркетинге. На выбор компании для анализа повлияло, в частности, и то, что разные представители компании утверждали, что «Mondelēz International» использует глокальную стратегию для продвижения своей продукции в разных странах мира. Маркетинг-микс компании «Mondelēz International» рассмотрен в данной работе на примере товаров под торговыми марками «Barni», «belVita», «Oreo», «Picnic», «Tang», «Toblerone». Результаты. В работе обобщены теоретические основы глокального маркетинга, а также рассмотрены практические примеры применения такого маркетинга. Между странами существуют многочисленные различия, в частности: 
социальные, технологические, экономические, экологические, политические, правовые, этические и другие. Это означает, что маркетинг в разных странах имеет как общие, так и отличительные черты. Локальные аспекты маркетинговой деятельности влияют на определение глобального маркетингового направления компании. В то же время каждая глобальная маркетинговая проблема имеет свое локальное выражение, и, следовательно, требует глокального подхода к решению проблемы. Глокальный маркетинг - это маркетинг, который объединяет преимущества глобального и локального подходов, учитывает тенденции и изменения маркетинговой среды, порождённые диалектикой единства и борьбы глобального и локального. Объединение идей глобального и локального маркетинга позволяет смягчить или даже полностью избежать тех недостатков, которые проявляются, если применять только глобальный или только локальный подход. Одни итеже товары компании в разных странахмогут иметь разное название или вариацию вкусовыхдобавок, выпускаться в различных формах. Цена на товары зависит от цен на производственные ресурсы. Компания «Mondelēz International» часто прибегает к варианту уменьшения веса своих товаров, чем к повышению цен. «Mondelēz International» реализует свою продукцию в 165 странах мира, которые организованы в пять регионов. Каждый из этих регионов имеет свою структуру потребления товаров компании и другие особенности. Продвижение товара зависит от особенностей данного товара: позиционирование может не отличаться в разных странах, но в рекламу могут быть внесены изменения в зависимости от рынка, если такие изменения необходимы. Анализ различных источников информации, а также исследование маркетингмикса на конкретных примерах подтверждают использование глокального маркетинга компанией «Mondelēz International». Практическое значение. При рассмотрении теоретических основ исследования были выделены преимущества и в то же время характерные черты применения глокального маркетинга, которые также были подтверждены конкретными примерами деятельности «Mondelēz International». Исследование подтвердило существующие теоретические достижения в сфере глокального маркетинга, а также является продолжением и дальнейшим развитием данных достижений, концепций и идей. Значение/оригинальность. Конкретные примеры деятельности «Mondelēz International», приведённые в данной статье, в сочетании с теоретическими основами рассмотрения вопроса глокального маркетинга, составляют логическое единство и взаимодополняемость. Получило дальнейшее развитие научное понимание понятия «глокальный маркетинг», а также применение его принципов на практике, что поможет, в частности, крупным транснациональным корпорациям эффективно вести свою деятельность на рынках разных стран в условиях культурной дифференциации, которая проявляется в разнообразии потребностей, вкусов и предпочтений местных потребителей. Всё это призвано уменьшить расходы и повысить доходы подобных корпораций в условиях современной маркетинговой среды, а также максимизировать удовлетворение потребностей потребителей в разных странах. 